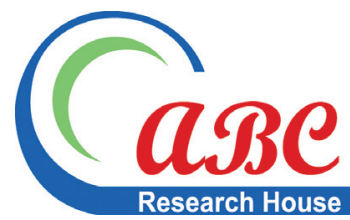

\title{
Innovations of Housing Finance Systems and the Implication in Bangladesh - A Categorical Study on Financial Markets
}

\author{
Sanjoy Pal ${ }^{1}$, Mohammad Sharif Hossain ${ }^{2}$ \\ ${ }^{1} M B A$, Department of Banking and Insurance, University of Dhaka, Dhaka, Bangladesh \\ ${ }^{2}$ Senior Lecturer, Dept. of Business Administration, Uttara University, Dhaka, Bangladesh
}

Access this article online

Website:

www.ajtp.us

Volume 1

Number $1 / 2014$

Issue 1

DOI:

Licenced: (C) $\$$

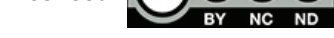

E-mail for correspondence:

sharif1400@gmail.com

Received: April 27, 2014

Accepted: June 15, 2014

Published: June 30, 2014

\section{ABSTRACT}

An evolution in the system of investment and finance, is being seen everywhere not only in the emerging economy but also in the economy of developing countries including Bangladesh, is housing investment. A feature by its nature is a long term investment arena that requires cash or cash equivalent to grab the real asset legally. Now a country with a lot of human resources like Bangladesh is under the frustration raised by the security investment which just is going to crash down the probable site of investment by its negative feedback. Now housing investment is the last resort of investment that gives reasonable outcome and that's why it is exigent to analyzing the framework of housing finance system in Bangladesh. This paper addresses the parley relating to the financial system and the sources of housing finance in the commercial sector of Bangladesh. A group of model here represents the developing scenario of real estate financing and how to assure of the sources of finance, how to get the services provided by the financial institutions and overall, to measure the results according to market transparency.

Keywords: Evolution of house financing, Mortgage lending, Mortgage intermediaries, Mortgage finance industry in Bangladesh

\section{Introduction}

Real Estate is the investment sector of the maximum return, backed up by a fewer risk. Bangladeshi people are now losing their financing capital for the continuing economic downturn that is making a dam between the investors and the investment projects. So, most of the average incoming persons are now on the way of searching housing finance that has a long term feedback of gradual development. Without a formal financial system in the least developing and developing countries, housing finance is either self-financed or mutually direct-financed which include the friends, relatives and so. In Brazil there are savings institutions or lending clubs and landlords in Korea. The present phenomena support, the informal arrangement of household seeking, is always inefficient that will make hesitation between the borrower and lender to achieve their expected scale. In Bangladeshi market information is scattered (not equally shared) which pushes the finance not to get and volatiles the risk management area of concentration.

The another type of direct finance exists in most of the emerging economy such as Brazil, Turkey and Egypt, which is installment basis sales contract where there is no chance of observing the construction on time, and they have to bear the total risk of housing. That is a problem of financing that is further rejected by Russia, Ukraine, Turkey and China (Lea 2009).

In a growing economy like Bangladesh, it is now a matter of concern to provide the finance to individuals to make them able to construct a house for living. And indirect finance joined a new era of housing finance by the money market participants (financial institutions); like that Bangladesh has commercial banks, savings and loan associations (microfinance organizations), mutual savings banks (cooperative societies), 
Islamic banks and insurance companies. Historically, a group of models were prepared on the real estate financing where the original existence was under the uncertainty. But, in Bangladesh it is one kind of eclectic hotchpotch to provide the housing finance properly. Therefore, and a group of financial institutions had broadened the particular market and liberalized the housing finance systems.

\section{Literature Reviews}

Finance is to collect fund and invest the money in an efficient way for the purpose of maximizing profits. Both direct and indirect finance are noticeable in financing for housing. And the need for housing is explained by a lot of experts in their own view:

A report of Center for Policy Dialogue (CPD) bespeaks the right of every person is the demand for the basic needs that include a standard of living that can be most appropriately figured out by housing he/she availed. But now-a-days the shelter is going to be a challenge to the people of Bangladesh for limited land according to the nation's population growth rate that has plateaued at 1.37 percent found in the Fifth Population Census up to March 15, 2011 report that published on July 16, 2012. That indicates the further crying need for Bangladeshi people will going for accommodation.

Though categorization of house lending is not necessarily a proposition for funding money by the middle and lower classes of people for their living, lack of effectiveness of the proper authority ensures making hesitation to the public to get a moderate home loan from financial institutions. Dr. Bhattacharya, an economist and reformist, emphasizes the importance of the housing sector in the economy of Bangladesh, which plays a role for the awareness generation regarding relevant issues of housing sector mentioning to serve the shelter as a fundamental right of a citizen which includes the economy, market structure, market trends, legal and regulatory framework and related challenges.

Marja C. Hoek-Smit identifies, in a research conducted on Bangladesh's Housing Finance, the lacking of government initiatives and hurdles in improving the housing conditions for middle and lower income households. In 1998, he assessed the mortgage lending system and concluded four major impacts playing simultaneously for lending to household:

1. The non-transparency of government's mortgage lending process

2. The encouraging of debt acquisition than deposits or savings due to subsidized interest-rate programs that took place in Africa, Latin America as well as in Asia.

3. Providing a little mortgage lending according to the formal house finance system.

4. The inability of affording the start-up costs for having collateral mortgages.

John F. McDonald \& Houston H. Stokes mentioned the falling downturn of people's inability of housing due to the bubble increased pricing of the house, apartments, and lands for the middle and lower incoming people of Bangladesh. According to observation of The Financial Crisis Inquiry Commission (2011, pp. 84-85), the homeownership is cut by the low rates of interest. The downturn economy affected by the investment in the stock market made the episode for thinking about house lending by financial institution.

\section{Objectives of the Study}

The private financial institutions are actuating well and bringing out the new structure of housing finance. The objectives of the study are:

- To identify the sources of house financing

- To identify the financial institutions involved in the house financing sectors

- To measure the effect of financing from primary market and secondary market

- To find out the probable lending models which are given by the financial market leaders

- To observe the moving module of single-handed and multihanded system of house financing

- To explore the present situation of housing finance in Bangladesh

- To show the tradeoff between borrowers and lenders for real estate finance by evaluating the information.

\section{Rationale of the Study}

Despite the verbal disputes over the borrowing for house construction from the indirect methods of financing, the formats of policies regarding the housing finance are available in the financial market. But all individuals are not aware of these that drive to direct finance and most of them are not performing well in repayment of their collected money. So, the analysis is needed to ensure what the consequences of housing finance from financial institutions are.

\section{Data}

The report has been conducted based on the secondary data available in the institutes including, Centre for Policy Dialogue (CPD), Real Estate and Housing Association of Bangladesh (REHAB), Bangladesh Bureau of Statistics (BBS), Bangladesh Banks (BB), and published articles of renowned journals and the data of yearly budgets and financial institutions of Bangladesh.

\section{Research Methodology}

The data has been processed with the interview of key personnel of banking and non-banking financial institutions. For the selection of organizations, a random sampling procedure has been applied that includes different sectors such as banking, leasing, insurance companies and so on from financial markets of Bangladesh. And a group of data (secondary data) regarding housing finance has been taken from available sources of inside and outside Bangladesh to find out the western way of house financing and the deviation of system in Bangladesh to analyze the research in a broader perspective. 


\section{Research Analysis}

The last few decades indicate the derivation of housing finance in Bangladesh. A lot of comprehensive studies gave us the knowledge about the housing markets and the housing finance system. Since 1980, Bangladesh has been facing the economic growth that makes the country to develop the area of concentration in several concerns. It is quite clear the financial sector is the most productive sector in the economy. But the sector has to depend on the others to be developed. And Real Estate Sector is the only stage of distribution of land and house to the nationals. The falling demand has been seen in 1980 to 1990. But the growth of Bangladeshi nationals knocks at the door of developing housing finance from 1991 to 2000. And a huge inclination has been seen from 2001 to 2011 as the entry of the reliable developers.

The mere trade organization of real estate developers in Bangladesh is REHAB, with a current membership of 260 Developers. A large portion of revenue to the Government exchequer in the angle of Registration Cost, Utility Service Charges as well as Income Tax is contributed by the members of REHAB (rehab-bd.org. 2014)

Government of Bangladesh has distributed an allocation of Tk. 1461.74 crores for FY 2012-2013 where Tk. 2189 crores for FY 2011-2012, composed of both development and non development budgets, for land management and housing sector as the land scarcity and high price constitute a challenge for the government in its efforts to ensure housing for low and middle income people as pledged in 'Vision 2021' (Budget Speech 20112012). The housing budget is 0.6 percent of non-development budget. Emphasizing the theme of 'Housing for All' there is an inauguration of the construction work of a multistoried building of 22500 flats at Uttara and in parallel there are a group of project started for the mediocre people and till February 2012 Tk. 132.50 crores out of an allocation of Tk. 160.50 crores is used for 51368 flat construction to provide shelters for the poor people.

Along with the huge population, grew up of safety housing projects and standard of livings allow people to have a home, an apartment, and as well as a land. But the demand for housing is not equivalent to the level of income and price hike with the rate of inflation. To procure these, everyone has to collect money from the available sources as financing.

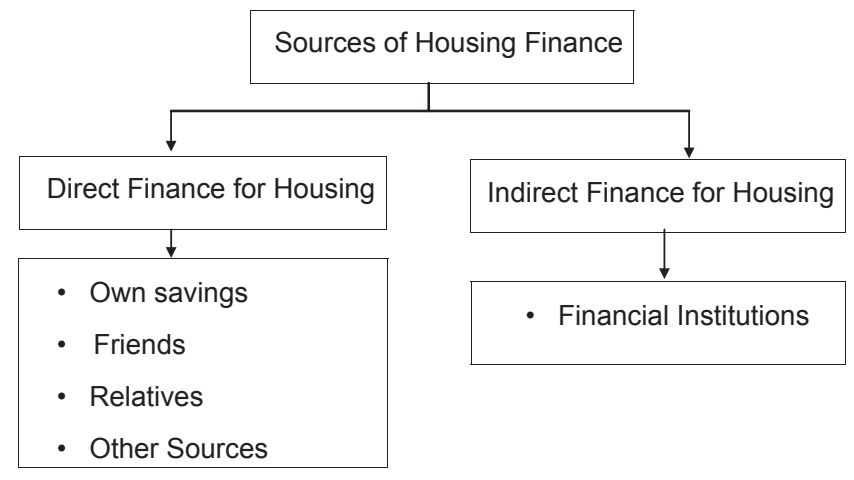

Figure 1: Sources of housing finance
There are two sources from where one can collect the fund for housing. The paper is contained of indirect finance for housing that includes the financing from financial institutions. The involvement of several firms in the housing finance markets had been observed from the mid $19^{\text {th }}$ century. Statistics shows that Bangladesh will need to construct approximately 4 million new houses annually to meet the future demand of the next twenty years. Estimates for annual requirements for housing in urban areas vary from 3 lac to 5.5 lac units. Rather than being a phenomenon specific to Bangladesh (CPD, Report No: 64), urbanization has now become an issue of global concern.

\section{Mortgage Lending Models}

The funding criteria innovated for house financing by formal financial intermediaries is a sign of financial sector development, where the institutions may be private sector entities, or state- sponsored or state-owned firms. Here, we are to see the interference of financial intermediaries for various models of housing finance system as a product named mortgage. Organizations participated in mortgage markets are as follows;

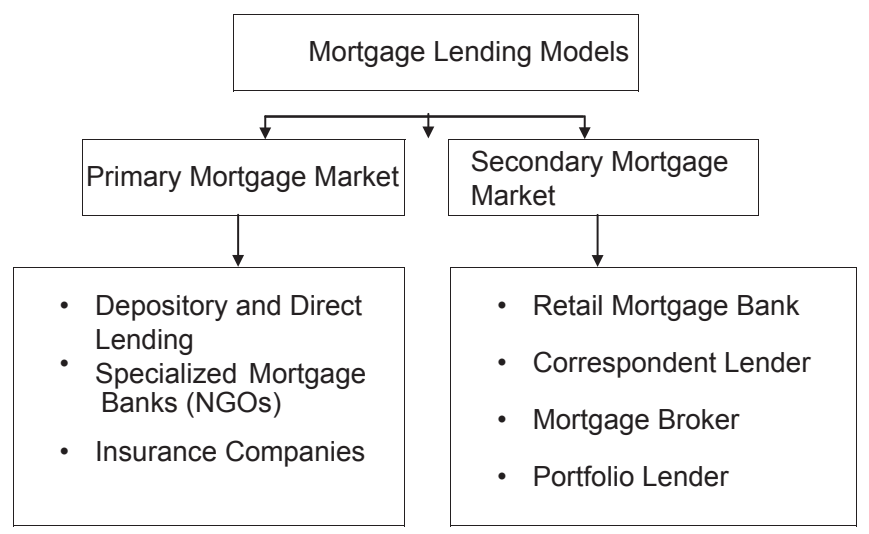

Figure 2: Mortgage lending models

Mortgage lending depends on the two types of markets; the first one is the primary mortgage market, and the last one is a secondary mortgage market.

\section{Primary Mortgage Market}

The market comprises of depository and direct lending institutions and the specialist mortgage banks that provide the mortgage loan into different modes. Specialist-deposit-funded institutions have traditionally dominated the provision of housing finance in AngloSaxon countries (for example, Australia, South Africa, Canada, and United States) in addition to Commonwealth countries (Lea 2009). The previous contribution of specialized mortgage banks is not as little as the mortgage market maker.

Direct and Depository Lending

The traditional and still market leading mechanism for the formal financial sector of housing finance is the retail depository institution. The followings are the only participants in house financing that maintains the methods of direct lending. 
Pal and Hossain: Innovations of Housing Finance Systems and the Implication in Bangladesh (32-41)

\begin{tabular}{|c|c|c|}
\hline Types of Depository Institution & Primary Liabilities & Primary Assets \\
\hline $\begin{array}{l}\text { 1. Savings and Loan } \\
\text { Associations } \\
\text { (Microfinance Organizations) }\end{array}$ & Deposits & Mortgage Loans \\
\hline $\begin{array}{l}\text { 2. Commercial Banks } \\
\text { 3. Mutual Savings Banks } \\
\text { (Cooperative Societies } \\
\text { \& Credit Unions) }\end{array}$ & $\begin{array}{l}\text { Deposits } \\
\text { Deposits }\end{array}$ & $\begin{array}{l}\text { Mortgage Loans and } \\
\text { so on } \\
\text { Mortgage Loans }\end{array}$ \\
\hline 4. Islamic Banks & Deposits & $\begin{array}{l}\text { Mortgage Loans and } \\
\text { so on }\end{array}$ \\
\hline
\end{tabular}

Figure 3: Financial institutions in housing finance system

All the fund transferring depends on the primary assets and primary liabilities of institutions (Figure 3) as we know any types of market is the combination of buyers and savers for demand-supply.

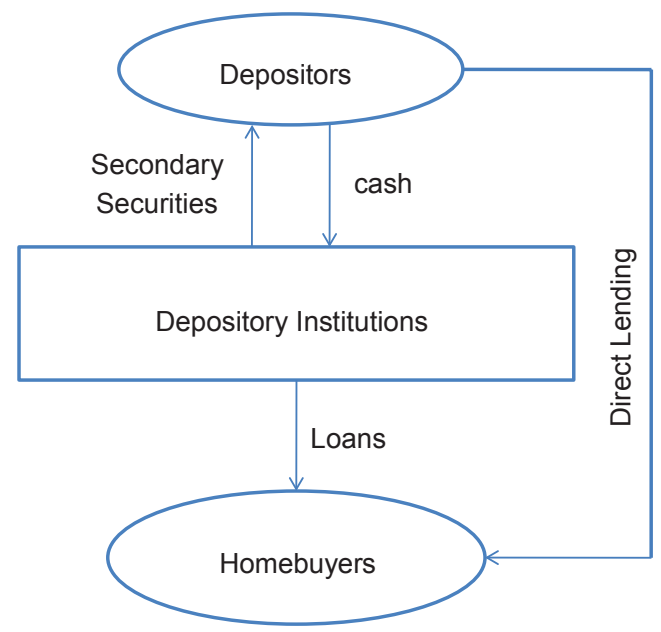

Model 1: Direct and depository lending procedure

According to Loanable Fund Theory of Interest Rate defined the supply of Loanable fund creates from the households or individuals or consumers savings, business enterprises, money creation by central banks and lending in the domestic market by foreigners. Normally, the financial organs gather savings from households and business enterprises as deposits and make mortgage loans to homebuyers. In model 1 , the depository institutions only get the Loanable funds from depositors against which the secondary securities (fixed deposit, savings deposit and current deposit) are issued. Then the depository institutions provide loans to the general public and corporations. A huge portion of the loan is distributed to homebuyers as housing loan.

\section{Savings and Loan Associations (Microfinance Organizations)}

The preliminary market dominant model for housing finance was the building societies before continuing operations of depositfunded organizations. Building societies were first founded in England in 1775. In Bangladesh, there is no savings and loan association separately. Instead of savings and loan associations there are same types of services offered by the microfinance institutions in Bangladesh such as Grameen Bank (the Noble Prize winning only firm in Bangladesh), BRAC, Association for Social Advancement (ASA) and as well as Proshika.

\section{Commercial Banks}

The historical evolution of commercial banks in housing finance is well-said as weak. They only took deposits and provided only the short-term loans to the organizational bases due to having certainty of return money than the individual investors. They led the commercial sectors just as the professional investors and paid a little attention in housing finance. But their product based area of concentration has been broadening day by day, which now has reached into the consumer oriented banking, and an outcome of this is retail banking that includes the mortgage loans separately. In many countries, the restricted commercial banking operation makes the real estate sectors volatile.

Now-a-days banks are turning to retail clients across the world in part including Bangladesh because of a loss from their huge investments of deposited money to the capital markets. Banks are interested in long-term mortgage loans arisen from fixed deposits that develop long-term consumer relationships and secured feedback. This type of bank can be the portfolio consultants as well as short-term construction and warehousing loan providers; and the lending firms in the secondary markets.

\section{Mutual Savings Banks (Cooperative Societies E Credit Unions)}

The economy of the west insisted cooperative types of organizations to mutual participation in lending so that the risk could be smoothly compensated. Now a significant market share has been grabbed by the Cooperative Banks in Netherlands and Germany. They are not considered as housing-finance specialists while they continue operations as mutual organizations. The institutional attendees of major mortgage fund lending in many European countries like Spain, Germany, and France are Savings banks (Lea 2009). They are often owned by state or municipal governments and can benefit under government backing.

In Bangladesh, there are some cooperative societies and credit unions operated by the private sector which are abused in their nature. Instead of helping the lower and middle incoming people, they are only running after the businessman with a high interest rate spread of providing the short-term loan. Because, there is no control in interest rate spread where in house financing it is merely rare.

\section{Islamic Banks}

Islamic banks are another market player in mortgage financing. These types of companies just grew up mostly Islamic countries such as Bangladesh, Pakistan. A simplified version of house finance is a sort of lease-buyback arrangement known as Murabaha. One of the popular house financing products in Islamic finance is Diminishing Musharaka, a declining balance/equity shared with which both parties share risks and obligations related to the property. Under the Murabaha loans, the banks buy properties and resell it to the client remaining buoyant, to own the property outright until the final payment paid out. The property outright is a plan offered by the bank as a level of security not available with a traditional mortgage. 


\section{Specialized Mortgage Banks or NGOs}

As a new mortgage markets specialist, one type of banks was born in the mid $17^{\text {th }}$. An alternative to depository institution (sometimes it may be Non-Government Organization) lenders is mortgage bank. Mortgage banks innovate and serve portfolios of mortgage loans which are funded by their issuing securities, (Model 2) in this system. The mortgage banking system from the late 1700s has been broadly used in Europe. Both the residential and commercial mortgages loans are provided by mortgage banks. They dominate the mortgage markets providing fixed-rate mortgages not floating-rate mortgages that are match-funded with corporate debts that will not make the burden to the borrowers for variable interest rate. Mortgage banks are efficient in producing collateral back-up loans, but like other specialized systems exercised in developed countries, mortgage banks are also in declining mode. Their specialization bounded their area of services, as their funding source does not match with their product selection and ability to provide other financial services.

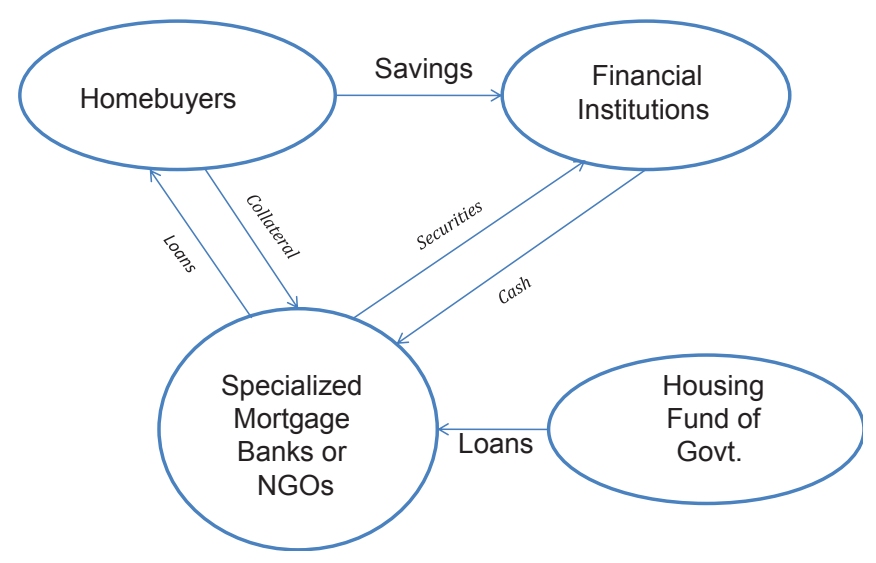

Model 2: Specialized mortgage lending system

\section{Box 1. BHBFC - Creating a Mortgage Market}

The House Building Finance Corporation (HBFC) was incorporated in 1952 to strengthen the housing sector when Bangladesh was known as East Pakistan, then in 1973 after the Liberation War it was renamed as Bangladesh House Building Finance Corporation (BHBFC) established with the first objective of enhancing home ownership by providing long-term finance to households for their housing needs in Bangladesh. After the war, all the area of Bangladesh was devastated, and the then government wanted to make the country as a nice living place, so, government made it with the total initial capital of Tk. 110 core with a paid up capital of Tk. 97.29. BHBFC financed all the money by issuing debentures and selling it to Bangladesh Bank and other commercial banks. And till June 30, 2006 the net asset value was Tk. 1283.83 core. BHBFC provided housing loans in 2 categories previously that has now classified into 7 categories. They provide housing loans maximum Tk. 50 lac and according to place it depends on. As of June 30, 201 1, BHBFC had about Tk. 2509.86 core in loan and advances outstanding.

Source: $B H B F C$
Most recent mortgage banks have lost their monopoly on covered bond issuance in Germany, and Denmark as a known phenomenon about the diversification of product choice with the changes over time makes the industry be distinct. Because competitions of markets wait for nothing, here the players gallop the profits initiating the diversified products or services according to market demands and also think about the future needs. There is no existence of these types of organizations in Bangladesh, but Bangladesh House Building Finance Corporation (BHBFC), and some NGOs provide the services here as offered by specialized mortgage banks.

\section{Insurance Companies}

Insurance company exists due to risk management for life as well as general purposes to diversify the future uncertain loss caused by a group of reasons. All people are here only for getting long term safety, and that makes the insurance companies to invest in the long term projects, unlike the banks. So, they also provide the housing loans as it is of long term nature.

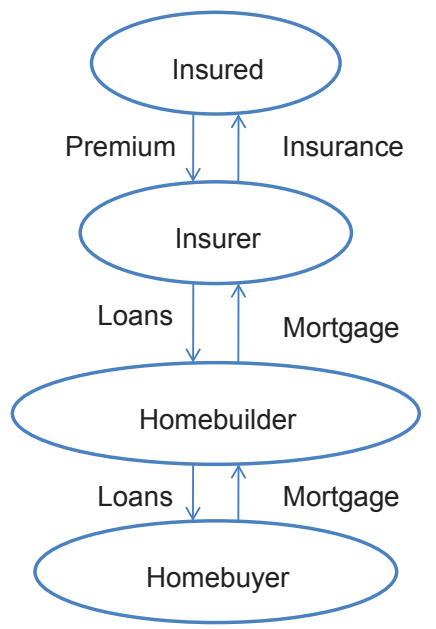

Model 3: Insurer mortgage lending system

The above model indicates other types of institution playing in financial markets, and since they get money from the insured for long term period, they are prone to safety investments. So, they accumulate funds only from insured against the insurance contract and offer loans to homebuyer against collateral.

\section{Secondary Mortgage Market}

The secondary market is a market where there are another party involved known as third party or broker or dealer. They just transfer the mortgage assets and securities between the buyer parties, and the party wants to change the right of owning the assets. As such, it involves the sale of the risks with selling ownership of mortgage loans to the third party. Banks and other financial institutions are the security providers of the secondary market where they trade the mortgage securities of several developer firms and they occasionally securitize pools of seasoned loans and expand the categories in the mortgage market. The market gained popularity for quick ability of liquidating the mortgage backed assets or securities that are still driving people for making money to housing industries. 


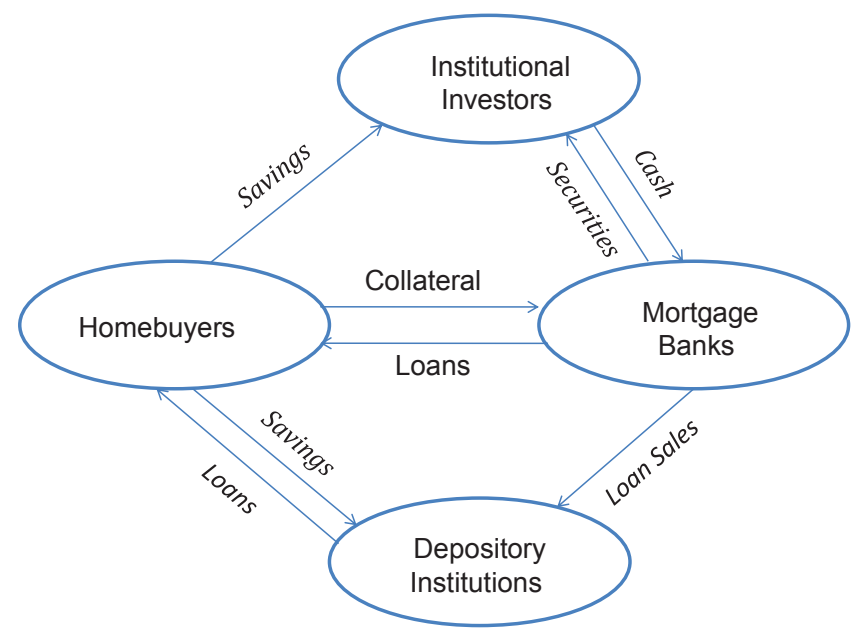

Model 4: Housing finance with a secondary mortgage market

Model 4 shows how the participants of secondary mortgage market exchange mortgage securities and bond as house financing. These entities raise funds through the issuance of collateralized securities by the loans and trade them. The majority of residential mortgage loans in the United States are funded through the secondary market (Lea 2009). The efficient market makers in secondary mortgage markets are: Retail Mortgage Banks, Correspondent Lenders, Mortgage Brokers, and Portfolio Lenders. Mortgage or housing finance companies are specialized non-depository institutions that obtain funds through sale of loans or circuit funding. Such types of institutions in Bangladesh are IDLC, Union Capital Ltd, BD finance, Bay Leasing, United Leasing, People Leasing, Uttara Finance, Prime Finance and so.

\section{Single-handed and Multi-handed Mortgage Models}

The functional separation or multi-handing is the emerging characteristic of mortgage markets in which specialists perform the various functions such as assess the assets, measure the ability of a borrower to pay amounts back, the time frame of a loan and so on underlying mortgage loan.

The single-handed and multi-handed system of financing is not for the mediocre people. The persons who are sufficient in money and would like to invest more in the housing sector, those are the exact choice for them. Because if a person wants to capitalize more and more, he then will want to stay out of negative feedback, and that's why he will take advice from the portfolio lenders. The lenders normally do the stepwise works for his client, known as single-handed model. Model 5 shows the single-handed model of mortgage lending firms according to its origination that separates the multi-handed model of mortgage lending as shown in model 6, where the market intermediaries are the functional area or separation as Retail Mortgage Banks, Correspondent Lenders, Mortgage Brokers, and Portfolio Lenders.

Here portfolio lenders may be specialized institutions such as savings and loan associations, building societies, specialized

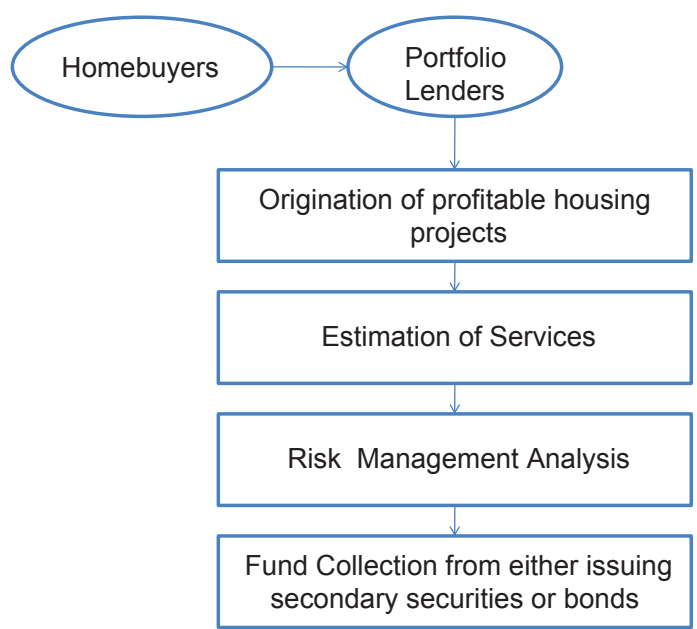

Model 5: Single-handed Mortgage system

mortgage banks, or general depository institutions. Mortgage intermediaries are the market participant work for both the borrowers and lenders who are increasingly important in the developed, as well as the developing countries. Introducer, brokers, are the entities that soothe the demands for housing to the individuals by originating the mortgage services such as real estate brokerage, financial advisory services, consultancy and building houses with legal assurance.

They are the more active market maker, because all the information is disseminated by the either man or through internet. They work on marketing of housing, underwriting of bonds to fund collection from capital market, managing risk, etc. As a developing nation, Bangladeshi people are going to be expert to operate internet while internet origination is not a stand-alone channel. It has to depend on other channels because the housing needs come from using the several hands for completing the demand for housing.

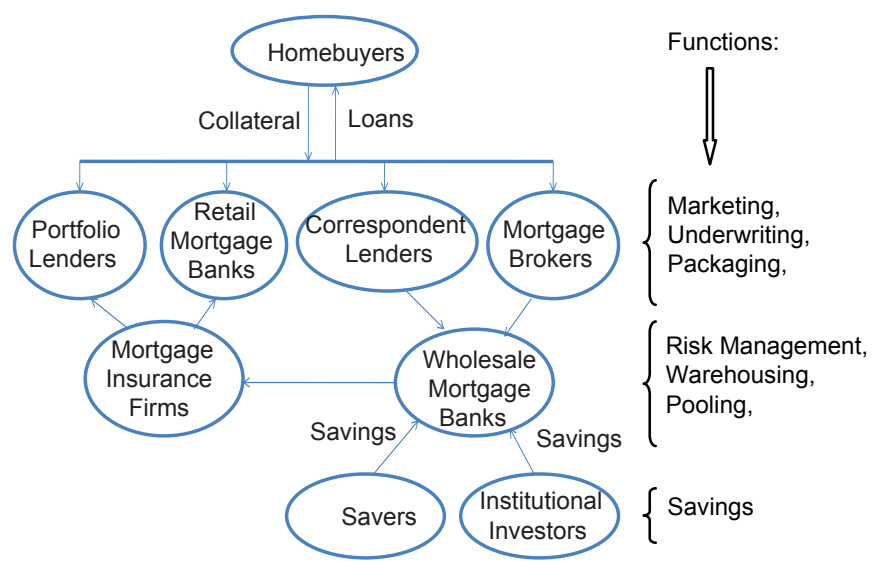

Model 6: Multi-handed Mortgage system

In the multi-handed system, there is a wide variety of investors to invest their savings but a risk is always occurred to get back all the lending money, known from the debacle of non-rearrangement of mortgage lending collection in 
USA in 2007. As part of providing housing loan, the credit risk management is more standard comparative to others, provided by third parties to absorb the borrowing cost of the borrowers, as well as the lending costs of financial institutions such as mortgage insurance or bond insurance companies for the benefit of investors. Competition, technology and the development are the leading drivers of mortgage securities to unbundling.

The work limits of intermediaries have been clipped in the multi-handed system right now due to having a few functions such as housing appraisal, and mortgage origination rarely and sometimes issuance of mortgage default, which now becomes an important catalyst for mortgage lenders and borrowers.

\section{The Present Scenario of Housing Finance Industry in Bangladesh}

Banking sector now dominates the house lending sectors in several ways. Banks take long time to approve a loan having a lot of operating costs per loan with a limited range of products. However, the state-owned Bangladesh House Building Finance Corporation (BHBFC) is the only institution that caters to the money needs of middle- and low-income groups for housing, which has sought the budgetary allocation of Tk 5 billion for the fiscal year 2013-2014 (Budget Speech 2014-2015).

The growth rate of South Asia Housing Finance Industry (chart below) just shows the position of Bangladesh comparative to other SAARC countries, where Bangladesh grabbed 14\% loan in the mortgage of total, India 13\%, Pakistan 20\%, Sri Lanka $30 \%$, and Afghanistan $40 \%$ of total. In South Asia, the banking sector dominates the mortgage sector; there is a small role of non-bank financial institutions in participation to mortgage lending. The corresponding information regarding the chart 1 is shown in annexure (Table 1).

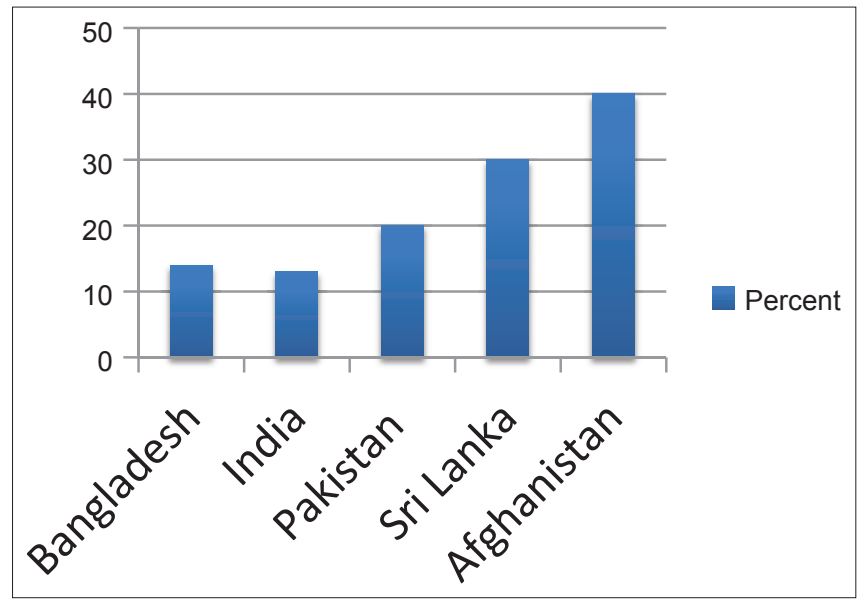

Chart 1: Housing Finance Rate with mortgage of the South Asia Housing Finance lindustry

Source: World Bank

Bangladesh has a total of Tk. 142.4 billion in the mortgage balance outstanding and the chart shows below also includes the market shares of different financing, a table regarding the pie chart is shown in annexure (Table 2).

Here, Bank mortgage financing is possessed of the $64 \%$ of the total balance, the maximum portion of mortgage lending, whereas the state specialized mortgage financing was $17 \%$; private specialized financing was $12 \%$, and Islamic mortgage financing was $7 \%$.

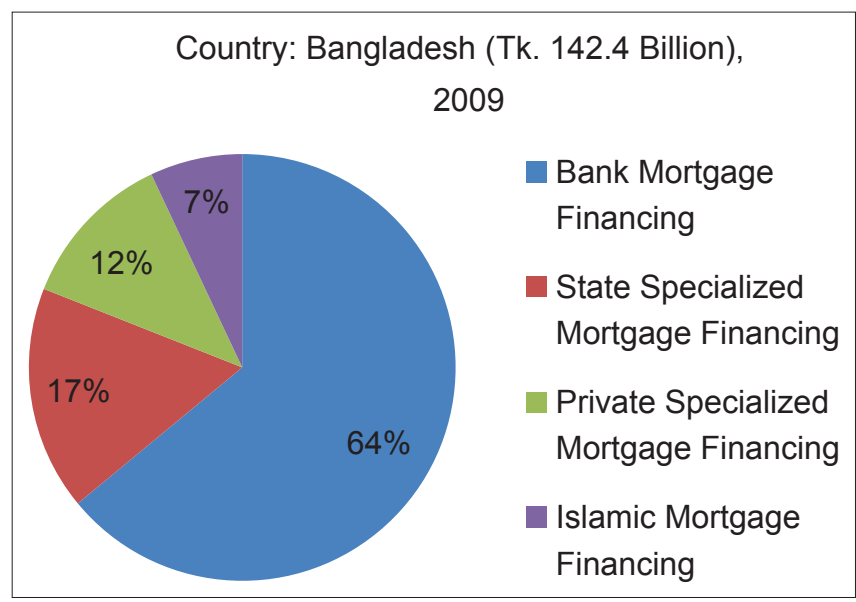

Chart 2: Total Mortgage Balances Outstanding and Market Shares Source: World Bank

\section{Contribution of Housing Fund of Bangladesh Government}

Shelter as the one of five basic needs of Bangladeshi people, the government of allocated Tk. 500 million for a housing fund to ensure the house for poor people as a task of poverty alleviation. Till March 2011, the amount stood at Tk. 1605 million. And the government allocated this fund to lend for housing by NGOs who take loan at 1 percent rate from the fund and offer loan for housing at the rate of 5 percent for the tenure of 10 years with the easy condition.

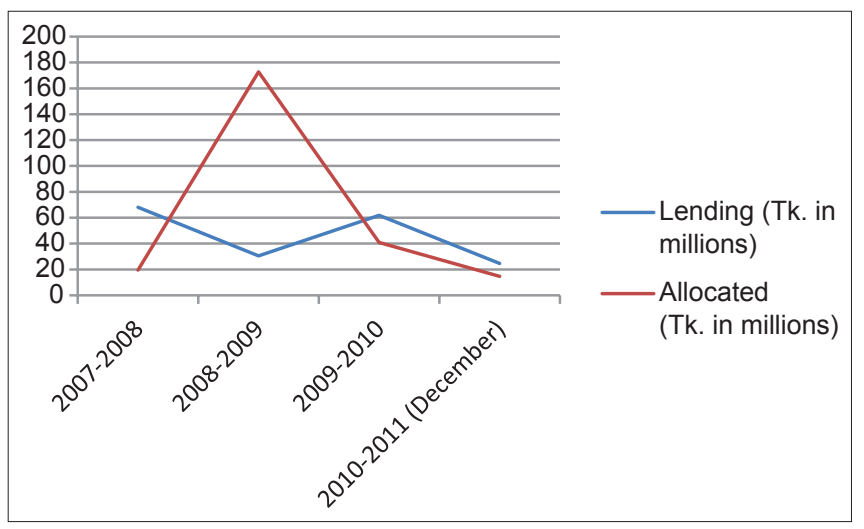

Chart 3: Loans Allocated and Provided from Housing Fund Source: Housing Fund, Bangladesh Bank

The above chart shows NGOs provided housing loans amounting Tk. 68.0 million against the allocation of Tk. 19.5 million in FY 2007-2008 and Tk.30.5 millions against the higher allocation of Tk. 172.8 million and in the following years the lending is greater 
than the allocation. To reduce the lending deficit, government had to allocate more in FY 2008-2009.

There was a higher person got facilities and more houses built in FY 2007-2008 due to greater loans providing in that year. And the amount of both reduced as the lending was less than half that of the previous fiscal year. FY 2010-201 1 includes the data of only first 6 months, which typically shows fewer houses built and facilitated persons comparative to the previous. The corresponding trend is shown in annexure (Table 3).

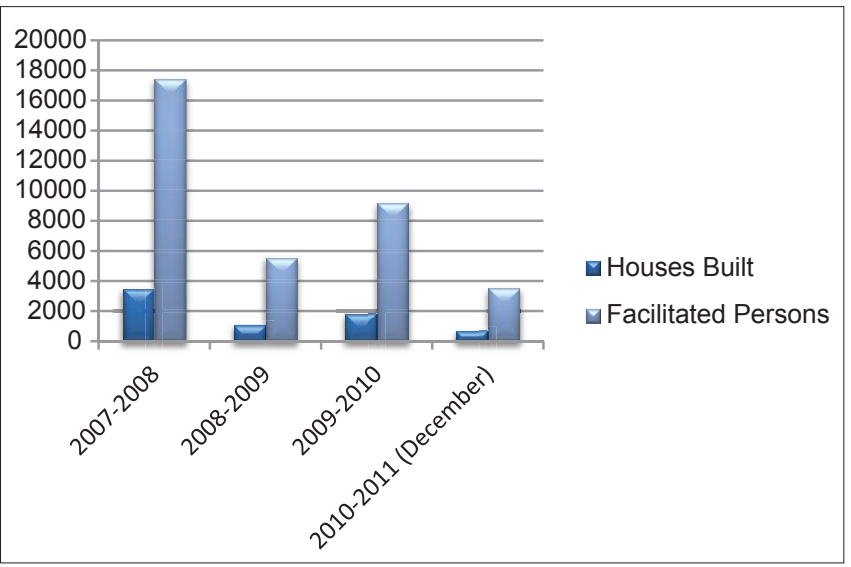

Chart 4: Total built houses and facilitated persons from housing fund Source: Housing Fund, Bangladesh Bank

And according to house financing need basis the corresponding housing structure in the urban as well as in the rural area is shown in annexure (Table 4 and Table 5 ) indicating the demand of people to go for constructing brick-cement made home as the land is limited mostly in the urban area.

\section{Problems Noticed in House Financing}

There are a group of pit-falls identified at the time of assessment the lending models of several countries and its effectiveness in the house financing sectors in Bangladesh, such the problems mainly are:

1. The country like Bangladesh has a lot of income regarding as undocumented cannot be invested in the housing sector because of feeling insecure.

2. Now-a-days no one can rely on the capital market that is well-known as the main source of long-term funds, which is used in the developed country for housing to the real estate company.

3. Formal house financing organizations are only willing for the distribution of fund to the public, nothing else.

4. The start-up cost of having a long term loan from the formal house financing associations is high.

5. The prohibition on real estate companies to procure their fund from the long term sources that make an apartment investor lose trust investing his/her money in the future housing projects.

6. There is not any reliable organization of housing property and securitized paper valuation for collateral lending in Bangladesh.
The drawbacks only are going to be the obstacles for house lending by the financial institution. But a positive sign can be obtained from the home loan ratio by the non-banking financial institutions in Bangladesh.

\section{Government Initiatives for Housing}

In order to rapidly increasing the housing sector in FY 1997-1998 government a total of Tk. 164 crore had released under the housing loan scheme. In the fiscal year 2010-2011,46,808 houses had been constructed at 400 Upazilas in 64 districts. The total number of beneficiaries of the scheme was 2,34,040 among which 60 percent represent women. Most countries in South Asia do not have specific prudential regulations for housing finance (Source: Budget Speech 2011-2012). Although the sophistication level ranges below standard in Bangladesh, but Bangladesh successfully finalized 'Real Estate Development and Management Act 2010' to promote the smooth expansion of house financing sector (Source: World Bank). Besides, the government is still working for the initiatives to work out a Detailed Area Plan (DAP) for the use of land in the divisional cities of Bangladesh. Budget of FY 2012-2013 (Section IV, subsection - 150) indicates the initiatives of developing 75688 plots and 212998 flats to build the satellite cities at Dhamrai and Kamrangir Char of Dhaka under PPP.

\section{Recommendations}

Housing Finance is the strategy for infrastructural development taken by the government of any country that is considered as the source of investments with maximum constancy though it contains the return at a fixed rate with long time. Bangladesh is the populace country including approximately 15 crore people with $1.37 \%$ of growth rate and an area of 147570 square kilometers whereas Pakistan with a population of 17 core and the area more than 6 times of Bangladesh. It ensures the land per head is decreasing day by day that shrinks the ambit of people which will create more demand of housing. Evaluating the study the following recommendations are mostly needed to boost the ambition of house financing of individuals.

- Interest rate spread, the gap between the rate of deposits and the rate of lending of financial institutions, should be lower. According to data published by Bangladesh Bank, the highest spread is being grabbed by the Woori Bank (a foreign bank operated in Bangladesh) that is 12.51 percent and among the local banks Dutch Bangla Bank Limited draws in 8.24 percent. But the experts recommend not incurring the spread more than 5 percent whereas the state owned banks are between 3.94 to 4.98 percent. The individual should have well-knowledge about this so that they can finance at a lower cost.

- The housing finance institutions have to arrange various training to fund collection and to use the amount for housing efficiently that will make the loan expansion of banking more fruitful.

- There should be a lot of seminar organized on the housing of individuals. It is well said that about 15 percent of people possessed with the 80 percent of development of Bangladesh, and the rest of the people only use the 20 percent. So, the 
regulator of financial institutions should make it sure the equal distribution of wealth and lending to people.

- More than 275 real estate companies operated in Bangladesh offering illusions that give people nothing but despair. The city dwellers are under the deception of them as there is no opportunity of purchasing land for housing, and they go for buying apartments. So, the infrastructural development with reliable papers should be cleared to individuals.

- Now-a-days the financial institutions involved in house financing only suggest the households the benefit of taking loan from them compared to others. But this is not sufficient as general people are fond of housing with insufficient knowledge of how to finance. So, financial institutions should tag the service of cost benefit analysis to individuals for house financing.

- Government can encourage the low and middle incoming people to make home in the least developed zones in Bangladesh by giving subsidies that is the best designed method of developing the housing sectors. Because property taxes is the highest source of government income in the city corporation of Bangladesh.

- Private finance sectors have to be given more right to provide their fund for housing which was proved efficient in most of the developing countries that diversifies the more subsidybased market to private sectors and makes the market not to distort prices.

After the consideration of above reactions by the government of Bangladesh, there will be no chance of falling down in the ascending order of housing and is still an opportunity of assuring the home for everyone that was discussed as a stunning point to developing the economy of Bangladesh.

\section{Conclusive Thoughts}

South Asian countries were under the regulation of British mostly that had no longer to be liberated. There is no noticeable improvement seen in the housing sector yet. Europe and USA mortgage markets are fully controlled by the financial institutions specially banks whereas Bangladesh is not. Now-a-days most banks are unwilling to house lending, while there is long investment horizon, because it includes the sanctioning of long term loan which is typically not permitted in the banking services, there is no authority for proper valuation of assets. It is noticeable in Bangladesh; the density of population is higher here. So, everyone deserves a piece of land for shelter or at least a flat for all. But, banks are feared to offer loan to them because of corruption everywhere such as accepting non-eligible property as a collateral, information of the property, and the financial institutions' information service regarding housing finance are not equally spread out, meager evaluation of client and their deficient tradeoff between income sources and expenditures. That's why a slow advancement in house financing in Bangladesh and other South Asian countries is considered as a disquieting picture. And insurance for property is so called active in book, not in practice from which financial institutions can assure of their lending recollection from client. In other countries, financial institutions perform as a dynamic actor, and incur the high productivity from the house lending sector. Excess demand for housing in Bangladesh makes the sector of Tk. 142.5 billion or a little over $6 \%$ of total credit to the private sector (World Bank 2009). But, inflation more than 2 digits drive markets to increase the prices of all the products available and a service with an assurance should be referred to spike the house financing demand instead of slumped down of the housing sector.

\section{References}

Lea, M. (2009). Structure and Evolution of Housing Finance Systems. In: Chiquier, L. \& Lea, M. (ed.) Housing Finance Policy in Emerging Market. The World Bank, Washington.

Uddin, A. K. M. R. (2003). Strengthening the Role of Private Sector Housing in Bangladesh Economy: The Policy Challenges. Report No. 64. Center for Policy Dialogue (CPD), Dhaka.

Hoek-Smit, M. C. (1998). Housing Finance in Bangladesh: Improving Access to Housing Finance by Middle and Lower Income Groups. University of Pennsylvania, Philadelphia.

McDonald, J. F. \& Stokes, H. H. (2013). Monetary Policy and the Housing Bubble. Journal of Real Estate Finance and Economics. Vol. 46, No. 3, February.

REHAB Profile [Internet]. Real Estate and Housing Association of Bangladesh, Dhaka. Available from: http://www.rehab-bd.org/profile [Accessed 16 January 2014].

Mujeri, K. M. (ed.) (2009), The Banking Sector, Capital Market and Non-Bank Financial Sector. Financial Sector Review. Bangladesh Bank, Dhaka.

Statistical Yearbook of Bangladesh [Internet]. Bangladesh Bureau of Statistics, Dhaka. Available from: http://www.bbs.gov.bd/ WebTestApplication/userfiles/Image/SY2010/Chapter-14.pdf [Accessed 22 March 2012].

BHBFC Profile [Internet]. Bangladesh House Building Finance Corporation, Dhaka. Available from: http://www.bhbfc.gov.bd/about.html [Accessed 19 August 2013]

Bangladesh Economic Review-2010 [Internet]. Finance Division, Ministry of Finance, Government of Peoples Republic of Bangladesh, Dhaka. Available from: http://mof.gov.bd/en/index.php [Accessed 15 December 2011].

World Development Indicators 2009 [Internet]. The World Bank, Washington. Available from: http://data.worldbank.org/indicator/ world-development-indicators-2009 [Accessed 09 April 2011].

Business in Brief (2011). Government urged to revive real estate market to rescue banks. Vietnam Net Bridge.14 December.

Huda, R. \& Kamal, M. (1998). Increasing Need for Institutional Credit in Housing Sector of Bangladesh. Journal of Finance \& Banking. Vol. 4, Number 1 \& 2, June.

Budget Speech 2011-2012 [Internet]. Ministry of Finance, GOB, Dhaka. Available from: http://www.docstoc.com/docs/82669986/BUDGETSPEECH-2011-12 [Accessed 12 July 2011].

Downs, D. H. \& Güner, Z. N. (2013). Commercial Real Estate, Information Production and Market Activity. Journal of Real Estate Finance and Economics. Vol. 46, Issue 2, February, pp 282-298.

Activities of Bank and Financial Institution 2010-2011. (2011). Department of Bank and Financial Institution, Ministry of Finance, GOB, Dhaka, May, pp 15-16.Appendi

How to Cite: Pal S and Hossain MS. 2014. Innovations of Housing Finance Systems and the Implication in Bangladesh-A categorical study on Financial Markets American Journal of Trade and Policy, 1, 32-41.

Source of Support: Nil, Conflict of Interest: None declared. 


\section{Appendices}

Table 1: House Financing Rate with Mortgage comparative to Total Loan Outstanding of the South Asia Housing Finance Industry

\begin{tabular}{lc}
\hline Country & $\begin{array}{c}\text { House Financing Rate with Mortgage } \\
\text { comparative to Total Loan Outstanding }\end{array}$ \\
\hline Bangladesh & $14 \%$ \\
India & $13 \%$ \\
Pakistan & $20 \%$ \\
Sri Lanka & $29 \%$ \\
Afghanistan & $40 \%$ \\
\hline Source: World Bank &
\end{tabular}

Table 2: Total Mortgage Balances Outstanding and Market Shares

\begin{tabular}{lllll}
\hline Country (Balance) & $\begin{array}{c}\text { Bank Mortgage } \\
\text { Financing (\%) }\end{array}$ & $\begin{array}{c}\text { State Specialized } \\
\text { Mortgage Financing (\%) }\end{array}$ & $\begin{array}{c}\text { Private Specialized } \\
\text { Mortgage Financing (\%) }\end{array}$ & $\begin{array}{c}\text { Islamic Mortgage } \\
\text { Financing (\%) }\end{array}$ \\
\hline Bangladesh (Tk. 142.4 Billion) & 64 & 17 & 12 & 7 \\
\hline
\end{tabular}

Source: World Bank

Table 3: Loans Allocated and Provided \& Total Built Houses and Facilitated Persons from Housing Fund

\begin{tabular}{lccccc}
\hline Particulars & 2007-2008 & 2008-2009 & 2009-2010 & 2010-2011 (December) & Grand total (up to December, 2010-2011) \\
\hline Allocated (Tk. in millions) & 19.5 & 172.8 & 40.9 & 14.6 & $2,221.1$ \\
Lending (Tk. in millions) & 68.0 & 30.5 & 61.8 & 24.6 & $1,351.4$ \\
Built Houses & 3,481 & 1,111 & 1,839 & 704 & 49,110 \\
Facilitated Persons & 17,405 & 5,555 & 9,195 & 3,520 & $2,45,550$ \\
\hline
\end{tabular}

Source: Activities of Bank and Financial Institution 2010-2011, Ministry of Finance, G0B

Table 4: Housing Structure (Main Houses) with Roof Material from Servey Reports

\begin{tabular}{lccccc}
\hline $\begin{array}{l}\text { Housing Structure (Main } \\
\text { House) Roof material }\end{array}$ & Urban & Rural & $\begin{array}{c}\text { Total (till } \\
\text { 2010) }\end{array}$ & Urban & $\begin{array}{c}\text { HIES 2005(Percent) } \\
\text { Rural }\end{array}$ \\
\hline Brick/Cement & 28.71 & 3.65 & 10.37 & 24.24 & 2.07 \\
CIS/Wood & 68.28 & 86.38 & 81.52 & 71.68 & 85.84 \\
Straw/Bamboo/Others & 3.01 & 9.97 & 8.11 & 4.08 & 82.25 \\
Total & 100 & 100 & 100 & 100 & 10.09 \\
\hline
\end{tabular}

Source: Consumption, Household Income and Expenditure, Statistical Yearbook of Bangladesh (Chapter-14), 2010, Bangladesh Bureau of

Statistics (Note; HIES: Household Income and Expenditure Survey)

Table 5: Housing Structure (Main Houses) with Wall Material from Servey Reports

\begin{tabular}{|c|c|c|c|c|c|c|}
\hline \multirow{2}{*}{$\begin{array}{l}\text { Housing Structure (Main } \\
\text { House) Wall material }\end{array}$} & \multicolumn{3}{|c|}{ HIES 2010 (Percent) } & \multicolumn{3}{|c|}{ HIES 2005 (Percent) } \\
\hline & Urban & Rural & $\begin{array}{c}\text { Total (till } \\
2010)\end{array}$ & Urban & Rural & $\begin{array}{l}\text { Total (till } \\
2005)\end{array}$ \\
\hline Brick/Cement & 56.59 & 13.59 & 25.12 & 48.23 & 9.92 & 19.63 \\
\hline CIS/Brick/Wood & 25.41 & 43.24 & 38.46 & 27.87 & 38.14 & 35.53 \\
\hline Mud/Unburnt brick & 6.22 & 22.12 & 16.72 & 5.97 & 22.15 & 18.05 \\
\hline Hay/Bamboo/Leaf/Others & 11.78 & 20.05 & 19.70 & 17.93 & 29.79 & 26.79 \\
\hline Total & 100 & 100 & 100 & 100 & 100 & 100 \\
\hline
\end{tabular}

Source: Consumption, Household Income and Expenditure, Statistical Yearbook of Bangladesh (Chapter-14), 2010, Bangladesh Bureau of Statistics (Note; HIES: Household Income and Expenditure Survey) 